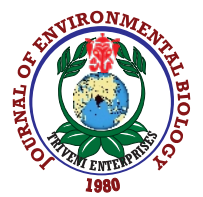

\title{
Diet composition and feeding strategy of crossbanded barb, Puntioplites bulu (Bleeker, 1851) in Perak River, Peninsular Malaysia
}

\author{
A.G. Intan-Faraha ${ }^{1,3 *}$, A. Arshad ${ }^{1,2}$, S.A. Harmin ${ }^{3}$, A. Christianus ${ }^{1}$ and M.I. Fadhil-Syukri ${ }^{1,2}$ \\ 'Department of Aquaculture, Faculty of Agriculture, University Putra Malaysia, 43400 UPM Serdang, Selangor, Malaysia. \\ ${ }^{2}$ International Institute of Aquaculture and Aquatic Sciences (I-AQUAS), Universiti Putra Malaysia, Jalan Kemang 6, Batu 7 Teluk Kemang, 71050 \\ Port Dickson Negeri Sembilan, Malaysia \\ ${ }^{3}$ Department of Science and Biotechnology, Faculty of Engineering and Life Sciences, University Selangor, 45600 Bestari Jaya, Selangor, Malaysia. \\ *Corresponding Author Email : azizarshad@upm.edu.my
}

\section{Abstract}

Aim: The present study deals with the diet composition and feeding strategy of P.bulu from Perak River, Peninsular Malaysia in relation to its development stage and size.

Methodology: Diet composition and feeding strategy of crossbanded barb, P. bulu captured from Perak, Peninsular Malaysia were studied between October 2015 and September 2016. Diet compositions were determined through a microscopic examination and feeding items were identified to the lowest taxonomic level possible. The feeding strategy for both stages (adult and juvenile) were determined based on Amundsen graphical method.

Results: Findings of this study revealed that this species is a planktivorous species that feeds primarily on Bacillariophyceae. Based on Simple Resultant Index, there are seven major diet items groups consumed by P.bulu in the population. Ontogenetic dietary shifts were perceived to be stage related, with adult stages consuming larger-sized prey while juveniles were predominantly herbivorous and fed primarily on smaller dietary items.

Interpretation: Puntioplites bulu inhabiting Perak River is planktivorous. This species demonstrated mixed feeding strategy and ontogenetic dietary changes was observed between juvenile and adult stages.

Key words: Feeding habits, Perak River, Planktivorous, Puntioplites bulu

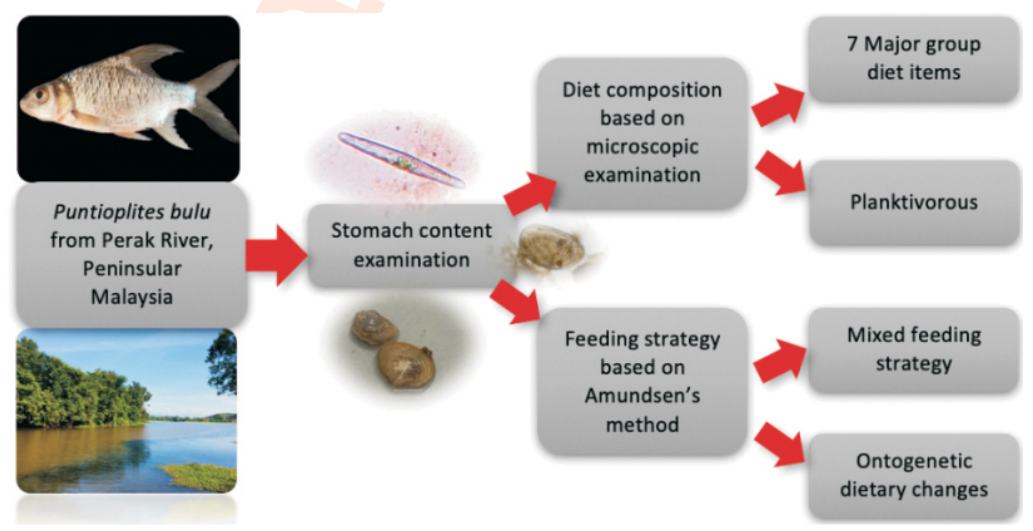

How to cite : Intan-Faraha, A.G., A. Arshad, S.A. Harmin, A. Christianus and M.I. Fadhil-Syukri: Diet composition and feeding strategy of crossbanded barb, Puntioplites bulu (Bleeker, 1851) in Perak River, Peninsular Malaysia. J. Environ. Biol., 41, 1399-1406 (2020). 


\section{Introduction}

Commonly known as the crossbanded barb, $P$. bulu is morphologically characterized by black patches and dark scales which form an oblique crossband on its body along with the nonserrated anal fin spine (Rainboth, 1996; Ambak et al., 2010). Puntioplites bulu is a freshwater cyprinid which is native to and widely distributed in South-East Asia. They are often found at midwater to bottom depths in large lowland areas such as lakes and rivers. In South-East Asia, P. bulu is found in Malaysia, Indonesia, Thailand, Vietnam and Brunei (Rainboth, 1996; Kottelat, 2005; 2013). In Malaysia, this specie is locally known as 'tengalan', and is found in main rivers and lakes such as Perak River, Pahang River, Kelantan River, Bera Lake as well as Chenderoh Lake and its distribution is well documented (Roshaliney, 2010; Hashim et al., 2012; Zulkafli et al., 2016; Radhi et al., 2017).

Sought after by fishermen and anglers due to its continuous demand and high market value which cost almost RM 50 per kg live weight (personal observation). However, despite of its high demand and market value, this species is now facing a fluctuating and declining landing trend due to several threats such as overfishing, climate change, presence of invasive species and habitat degradation resulting from rapid development activities (Yusoff et al., 2006; Ambak et al., 2010; Chong et al., 2010; Roshaliney, 2010; Hashim et al., 2012; Zulkafli et al., 2016; Radhi et al., 2017).

This valuable species has been reported to be an omnivorous species with their diet mainly on submerged aquatic plants, filamentous algae and benthic organisms (Kottelat and Widjanarti, 2005; Ambak et al., 2010). Information on the diet composition and feeding habits of a specie is indeed crucial in order to understand its ecological role and determining its position in food web ecosystem. The information gathered from this study would facilitate in species management for conservation and general aquaculture. As the diet items and feeding habits provide significant relation to their growth and development, the understanding on the feeding habits and diet preference could be the key factors to its culture prospect. In the area of feeding biology, knowledge on the diet composition and its feeding strategy are typically important due to the presence of various factors affecting the species diet preference and feeding strategy. Factors such as seasonal fluctuation, size selection, food obtainability and richness plays a significant role in the diet composition of most fish. There is also significant correlations between biological characters (mouth gape and size) with diet preference. Dietary shift during season and ontogeny development is to avoid competition within the population as well as allowing co-habiting existance (Khaironizam, 2010; Saikia, 2015; Yalcin-Ozdilek, 2017).

As it is not easy to observe the feeding habits of fish in their normal habitat, examination and identification on the stomach content of fish is perceived to be practical, achievable and commonly practice in fish feeding studies. While morphology of the fish can deliver an indirect suggestion on fish feeding activity, quantitative description on the diet composition based on frequency of occurrence and relative abundance can specify the relative importance of diet items (Amundsen et al., 1996; Simon et al., 2010). Feeding habits and dietary items of same fish species can be different within the population and this can be modified by the availability of food sources in particular area. Dietary items of $P$. bulu has been generally reported by Kottelat and Widjanarti (2005). Nevertheless, there is still a persistent need to increase the knowledge on the feeding biology of this valuable species since it is under threat and has potential for aquaculture industry.

To narrow the information gap, a comprehensive study on the stomach content and feeding strategy are taken in order to understand the ecological role of $P$. bulu in the ecosystem, as well as to understand their nutritional requirement for their culture success. In view of the above, the aim of this study was to determine the dietary items and feeding guild of $P$. bulu in the Perak River based on the stomach content examination, which includes the observation on feeding strategy and diet overlapping between juvenile and adult stage.

\section{Materials and Methods}

Study site and sampling procedure: A total of 256 samples were collected from Perak River, Peninsular Malaysia, specifically in Kuala Kangsar area $\left(4^{\circ} 46^{\prime} 25.7^{\prime \prime} \mathrm{N} 100^{\circ} 56^{\prime} 42.7^{\prime \prime} \mathrm{E}\right)$ (Fig. 1). All samples were obtained from a local fisherman on a monthly basis from October 2015 to September 2016. All samples were caught using a $2.5 \mathrm{~cm}$ mesh size gill net. Samples were systematically identified based on the main morphological characters described by Rainboth (1996) and Ambak et al. (2010). In order to minimize digestion and decomposition of stomach contents, all samples were chilled during transportation to the laboratory.

The length (total length and standard length) and body weight of samples were recorded to the nearest $0.01 \mathrm{~cm}$ and 0.01 $\mathrm{g}$, respectively. Mouth gape width (GW) and mouth gape height $(\mathrm{GH})$ were measured to the nearest $0.1 \mathrm{~mm}$ by using Mitutoyo digital caliper which was inserted into the fish mouth gape until marked resistance was reached. Due to the absence of sexual dimorphism, sexes and maturity of the samples were determined by internal gonad inspection which was conducted after all measurement was taken.

Gut fullness and feeding intensity: In laboratory, gut was cleaned and subjected to gut fullness analyses. All guts were removed and put in separate vials containing 10\% formalin. The fullness index was calculated by the formula given by Hyslop (1980). 


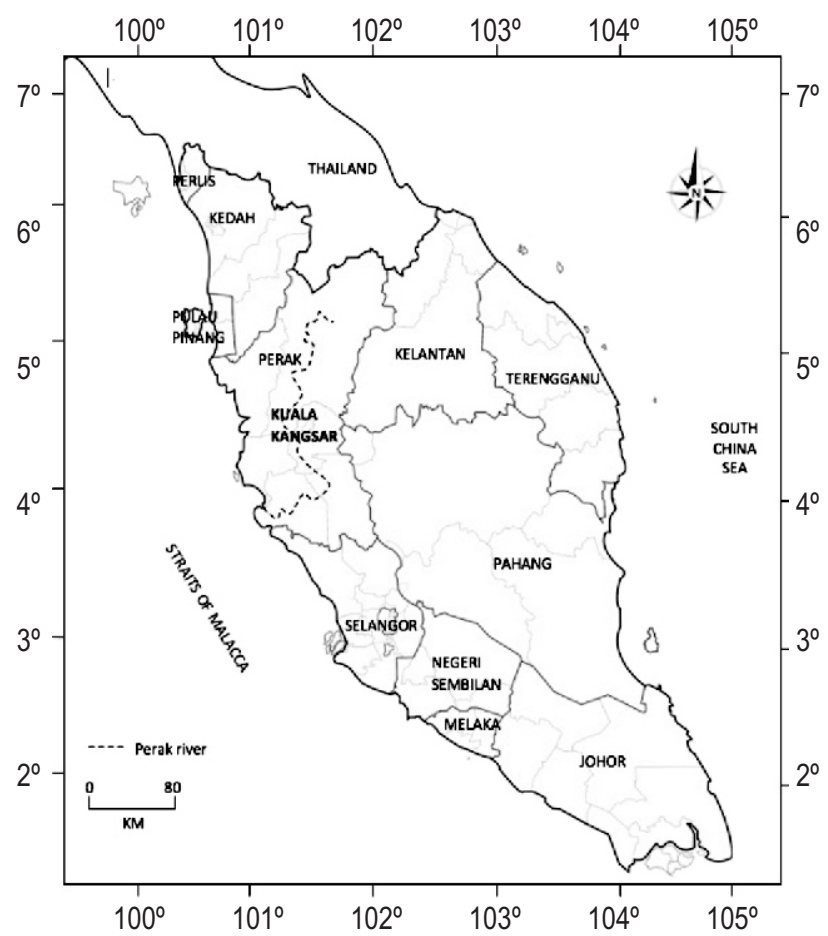

Fig. 1 : Peninsular Malaysia map showing sampling location in Kuala Kangsar, Perak.

Fullness index $(\mathrm{FI} \%)=($ Stomach content weight $/$ Fish body weight) $\times 100$

Diet analysis procedure: Prior to analysis, the gut was opened and its contents were placed in a petri dish and washed with 1 to 5 $\mathrm{ml}$ distilled water. A $0.1 \mathrm{ml}$ of gut content from the petri dish were placed on Sedgewick rafter counting cell and the gut contents were determined through a microscopic examination at suitable magnification. All food items were classified into large taxonomic groups and identified to the lowest taxonomic level possible.

The gut contents of $P$. bulu were analysed by using frequency of occurrence percentage (Fpi) and numerical percentage (Ci) (Chrisfi et al., 2007; Khaironizam, 2010; Seifali 2012; Arshad et al., 2013; Yazicioglu et al., 2017). The major food items consumed by $P$. bulu were determined based on Simple Resultant Index (\% RS) according to Mohan and Sankaran (1988). All formula is described as follows:

Percentage frequency of occurrence $(\mathrm{Fpi})=\frac{\mathrm{N}_{\mathrm{li}}}{\mathrm{N}_{\mathrm{p}}} \times 100$

Where, $N_{\| i}$ is the number of gut in which food items I was found and $\mathrm{N}_{\mathrm{p}}$ is the number of non-empty gut (Chrisfi et al., 2007).

Percentage of numerical abundance $(\mathrm{C} i)=\frac{\mathrm{N}_{\mathrm{i}}}{\sum_{\mathrm{i}=1}^{m} \mathrm{~N}_{i}} \times 100$

$\mathrm{N}_{\mathrm{i}}$ is the number of ith food item and $\mathrm{m}$ is the number of food item.
Simple resultant index $(\% \mathrm{Rs})=\frac{\sqrt{C i^{2}+F p i^{2}}}{\sum_{i=1}^{m} \sqrt{C i^{2}+F p i^{2}}} \times 100$

Fpi is percentage of occurrence frequency and $\mathrm{C} i$ is the numerical abundance percentage (Mohan and Sankaran, 1988).

Diet overlap analysis: Diet overlap analysis between adult and juvenile stages was analyzed based on Schoener's overlap index (Schoener, 1971) by the formula:

$$
C_{x y}=1-0.5\left(\sum_{i=1}^{n}\left|P_{x i}-P_{y i}\right|\right)
$$

where, $C_{x y}$ is overlap between individual diets of adult and juvenile stages, $P_{x i}$ is the proportion of prey I used by adult stage; $P_{y i}$ is the proportion of prey l used by juvenile stage; $n$ is the number of prey. Index ranges from 0 (no prey overlap) to 1 (complete overlap) with values greater than 0.6 were usually considered as biologically significant (Wallace, 1981).

Feeding strategy and feeding activity analysis: Feeding strategy of $P$. bulu were determined based on graphical analysis method of Costello (1990) with modification by Amundsen et al. (1996). The modified graphical analysis method combines the frequency of occurrence (Foi) with the abundance of specific food item $/(\mathrm{PI})$ in the formula:

$$
\left(\mathrm{FO}_{i}\right)=\frac{\mathrm{n}_{\mathrm{i}}}{\sum \mathrm{n}}
$$

where, $n_{i}$ is the number of fish which have consumed the food item $I$ and $n$ is the total number of fish that has eaten any type of food item.

$$
\left(\mathrm{P}_{\mathrm{i}}\right)=\Sigma \mathrm{S}_{\mathrm{i}} / \Sigma \mathrm{St}_{\mathrm{i}} \times 100
$$

where, $S_{i}$ is the number of gut content composed by food items taxon $/$ and $\mathrm{S}_{\mathrm{ti}}$ is the total gut content in only those fishes that have consumed food item taxon $I$.

Based on the graphical methods with modification from Amundsen et al (1996), diagram interpretation (prey importance, feeding strategy and niche breadth) can be obtained through the distribution points along the diagonal and axes of the graph. Points located at the upper left of the diagram denotes specialization by individual fishes, while plots represent the food item located at the upper right of the diagram denotes specialization of fish population. Meanwhile, plot located at lower right corner represents the food items consumed by most fishes in small number and plot at lower left of the diagram denotes rare food item consumed by the fish (Amundsen et al., 1996).

Statistical analyses: Aleast square regression was fitted for the relationship estimation between mouth gape and total length (TL) of the samples. Analysis of variance (ANOVA) was conducted in order to see significant difference of the fullness index (FI\%) and diet consumed between adult and juvenile stages. All statistical analyses was performed using SPSS 20 software package. 


\section{Results and Discussion}

Findings of this study provides early reference on the stomach content and feeding guide of $P$. bulu inhabiting Perak River, Peninsular Malaysia and also specify the foremost information on the ontogenetic dietary changes on diet composition as well as on its feeding strategy. The total length (TL) of 256 samples in this study ranged from $13.5-37.5 \mathrm{~cm}$ with the mean value of $20.8 \mathrm{~cm}$. Total lengths were significantly correlated with both mouth gape width and mouth gape height ( $p$ $<0.01$ ) (Fig. 2).

Fig. 3 depicts the gut fullness percentage of $P$. bulu from Perak River with $56.20 \%$ of the samples having a quarter full stomach compared to $6.59 \%$ of the samples with an empty stomach. The three-quarters full and half full stomachs were denoted by $9.3 \%$ and $27.91 \%$ of the samples, respectively. None of the samples were found to have full stomach. From all samples, based on the gonad inspection, 86 samples were classified as adults while 170 samples were classified as juveniles. Among the juvenile samples examined, $7.06 \%$ of them had an empty stomach, while $7.64 \%$ had three quarter-full stomachs. A similar

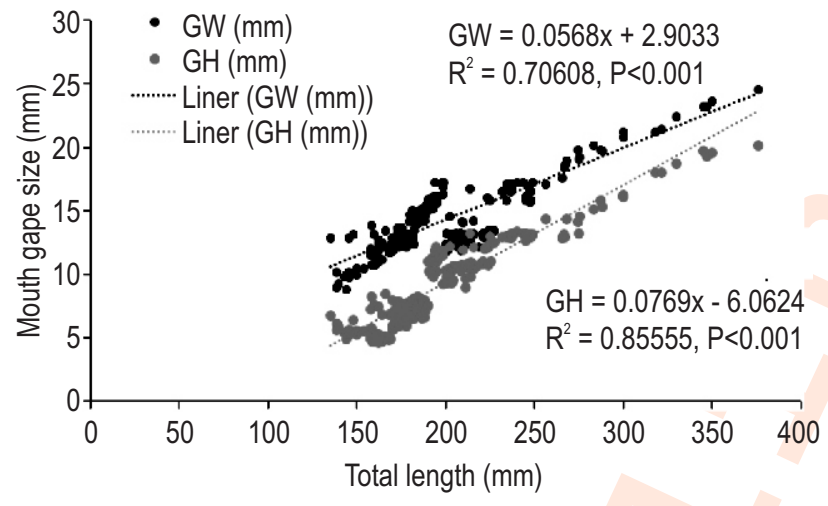

Fig. 2 : Linear least-square regression between total length $(\mathrm{mm})$ and mouth gape width $(\mathrm{mm})$ and between total length $(\mathrm{mm})$ and mouth gape height (mm) for P. bulu from Perak River, Peninsular Malaysia.

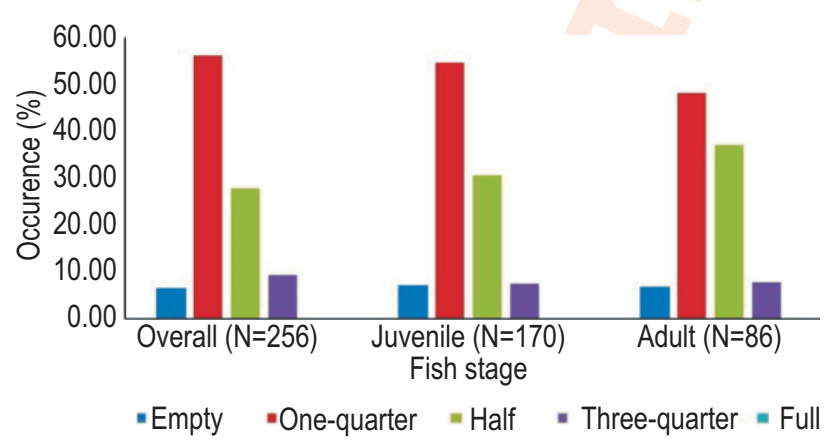

Fig. 3 : Percentage of stomach fullness of overall fish examined, juvenile and adult of $P$. bulu collected from Perak River, Peninsular Malaysia. The letter ' $\mathrm{N}$ ' indicates the number of fish used in the analysis. pattern with no significant difference $(p>0.05)$ was observed in adult stage samples with $6.91 \%$ of the adult samples having empty stomach, while $7.79 \%$ of the adult samples had three quarter full stomachs. However, a significant difference $(p<0.05)$ was observed for a quarter and half-full stomach with $54.71 \%$ being observed in juvenile stages as compared to $48.11 \%$ in adult stages for a quarter- full stomach. Meanwhile, for half-full stomachs, $30.59 \%$ and $37.21 \%$ were observed in juvenile and adult stages, respectively. Adult samples had high stomach fullness compared to juvenile samples. Feeding intensity of fish are usually related to its maturity stage and availability of food items in its environment (Al- Marzouqi et al., 2010; Yazicioglu et al., 2017). The findings of this study revealed that diet overlap was observed between adult and juvenile stages in the population, thus, competition among the two stages occurred and this could be the reason for higher percentage of stomach fullness among the adult samples. Moreover, at adult stage, fish fed more voraciously due to higher energy demand associated with gonad development. The stomach fullness analysis of $P$. bulu in this study displayed low to moderate fullness with none of the samples had full stomach. These conditions were probably associated to gut evacuation due to stress conditions during sampling and after being caught. Similarly, the same pattern with none of the samples observed with full stomach were reported for Neolissochilus soroides (Khaironizam, 2010).

Prey organisms and diet compositions found in stomachs of the P. bulu examined based on Simple Resultant index (\% RS) belonged to seven major groups consisting of 21 diet items (Table 1). Seven major group diet items comprise of worms $(0.8 \%)$, plant matter $(9.92 \%)$, Chlorophyceae (10.6\%), Mollusca (12.65\%), detritus (14.88\%), Crustacea $(21.26 \%$ ) and the highest diet item consumed by P. bulu inhabiting Perak River, Peninsular Malaysia was Bacillariophyceae (29.9\%) (Table 2).

Previously, P. bulu was reported to have omnivorous feeding habits because it consumed submerged aquatic plants, filamentous algae and crustacean (Rainboth, 1996; Kottelat and Widjanarti, 2005). Based on the findings of this study, the percentage of Bacillariophyceae was highest among other diet items consumed by all samples, thus, this specie can be categorized as planktivorous which feeds primarily on Bacillariophyceae. The abundance of detritus comprising woody materials, sand and related matter in almost all samples indicate this specie as a bottom feeder. The occurrence of small particles like sand and gravel might have been unintentionally engulfed while they were grazing on other diet items like molluscs. Its constructive mouth characters which is downwardly directed, supports its feeding habit and permits the intake of benthic organisms while its pharyngeal teeth are ideal for utilizing vegetation.

The feeding habits and diet consumed by fishes could be different among population, as dietary items are usually altered by 
Table 1 : Percentage of abundance and occurrence of diet items for $P$. bulu from Perak River, Peninsular Malaysia

\begin{tabular}{|c|c|c|}
\hline Food items & $\mathrm{Ci} \%$ & $\mathrm{Fi} \%$ \\
\hline \multicolumn{3}{|l|}{ Worm } \\
\hline Nematoda & 0.23 & 0.64 \\
\hline Oligochaeta: Naididae & 0.02 & 0.09 \\
\hline Total & 0.25 & 0.73 \\
\hline \multicolumn{3}{|l|}{ Crustacea } \\
\hline Copepoda & 0.51 & 1.48 \\
\hline Amphipoda & 0.36 & 0.89 \\
\hline Ostracoda & 16.99 & 6.61 \\
\hline Total & 17.86 & 8.98 \\
\hline \multicolumn{3}{|l|}{ Algae } \\
\hline Bacillariophyceae : Asterionella & 3.47 & 6.26 \\
\hline Bacillariophyceae: Cymbella & 3.95 & 6.51 \\
\hline Bacillariophyceae: Fragilaria & 6.01 & 6.58 \\
\hline Bacillariophyceae: Frustulia & 3.77 & 5.69 \\
\hline Bacillariophyceae: Gomphonema & 4.72 & 6.25 \\
\hline Bacillariophyceae: Navicula & 10.17 & 6.97 \\
\hline Bacillariophyceae: Pinnularia & 2.91 & 5.86 \\
\hline Bacillariophyceae:Stenopterobia & 3.00 & 6.31 \\
\hline Bacillariophyceae : Synedra & 3.35 & 6.56 \\
\hline Bacillariophyceae: Tabellaria & 3.83 & 7.06 \\
\hline Bacillariophyceae: Unidentified & 0.99 & 2.00 \\
\hline Total & 46.17 & 66.06 \\
\hline Chlorophyceae: Spyrogyra & 6.04 & 6.85 \\
\hline \multicolumn{3}{|l|}{ Mollusca } \\
\hline Gastropoda & 9.99 & 2.04 \\
\hline Bivalvia & 3.39 & 1.81 \\
\hline Total & 13.38 & 3.85 \\
\hline Plant Matter & 5.57 & 6.48 \\
\hline Detritus & 10.72 & 7.03 \\
\hline
\end{tabular}

Table 2: Overall diet composition of Crossbanded barb, P. bulu from Perak River, Peninsular Malaysia

\begin{tabular}{llll}
\hline Diet item & $\mathbf{C i}$ & $\mathbf{F i}$ & \%Rs \\
\hline Worms & 0.25 & 0.73 & 0.8 \\
Crustacea & 17.86 & 8.98 & 21.26 \\
Bacillariophyceae & 46.17 & 66.06 & 29.90 \\
Chlorophyceae & 6.04 & 6.85 & 10.6 \\
Mollusca & 13.38 & 3.85 & 12.65 \\
Plant matter & 5.57 & 6.48 & 9.92 \\
Detritus & 10.72 & 7.03 & 14.88 \\
\hline
\end{tabular}

the obtainability of food sources in that population. This species was previously reported as omnivorous species which consumed submerged aquatic plants, filamentous algae, crustacean, aquatic insects and small fish. (Rainboth, 1996; Kottelat and Widjanarti, 2005). Conversely, no aquatic insects and small fish were found in the stomach contents of $P$. bulu inhabiting Perak
River, Peninsular Malaysia which could be due to their absence in the sampling sites, competition with other species inhabiting same population or have been digested before stomach content examination.

Parallel findings were perceived on the dietary items of other species of Puntioplites from different populations. Population of $P$. wandersii from Kalimantan Barat, Indonesia was reported to have crustaceans, insects, small fish and organic matter in their diet (Kottelat and Widjanarti, 2005). However, $P$. wandersii from Cambodian Mekong on the other hand was found primarily herbivorous: with their diets more on aquatic macrophytes, swam- terrestrial vegetation, filamentous algae and some insects (Rainboth, 1996).

The findings based on numerical analysis of stomach content for $P$. bulu inhabiting Perak River, Peninsular Malaysia revealed 21 diet items consumed by both adult and juvenile stages. On the whole, the number of diet items consumed by juveniles were comparatively higher than the adult samples $(p<$ 0.05) (Table 3). Table 4 shows a higher percentage of Bacillariophyceae, plant matter and detritus consumed by the juvenile stages compared to the adult stages $(p<0.05)$ whilst the percentage of larger prey, i.e., Mollusca were much higher in the adult samples $(p<0.05)$. The percentage of worms and crustacean were similar for both adult and juvenile stages $(p>$ 0.05).

Feeding strategy analysis based on graphical plot added visual dimension to feeding pattern of fish figured from gut content data. Analysis of feeding strategy of $P$. bulu from Perak River, Peninsular Malaysia based on Amundsen's method, presenting both adult and juvenile stages have mixed feeding strategy that represent high variation within phenotype with varying degrees of generalization and specialization on different prey types. Fig 4 ascertains Bacillariophyceae with higher prey specific abundance and frequency of occurrence represents the

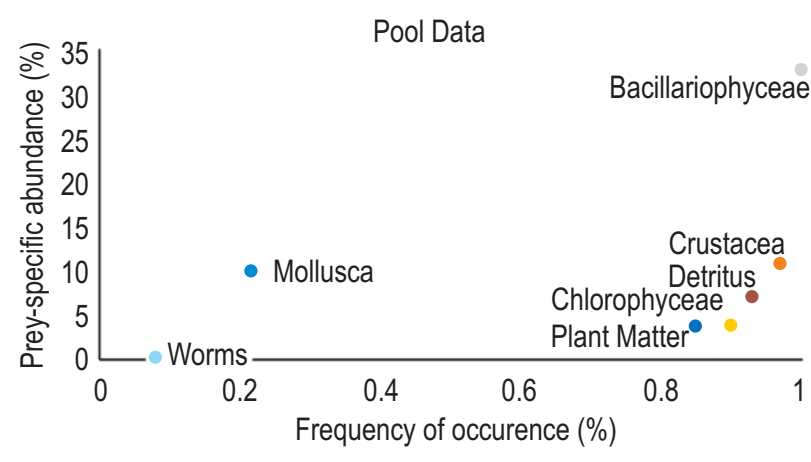

Fig. 4 : Relationship between prey-specific abundance and frequency of occurrence of diet categories in stomach of $P$. bulu from Perak River, Peninsular Malaysia (pooled data) based on the Amundsen's method (1996). 
Table 3: Abundance and percentage of diet items in stomach of adult and juvenile of Puntioplites bulu sampled from Perak River, Peninsular Malaysia.

\begin{tabular}{|c|c|c|c|c|}
\hline \multirow[t]{2}{*}{ Diet items } & \multicolumn{2}{|c|}{ Adult } & \multicolumn{2}{|c|}{ Juvenile } \\
\hline & $\mathrm{N}(86)$ & $\mathrm{Ci}(\%)$ & $\mathrm{N}(170)$ & $\mathrm{Ci}(\%)$ \\
\hline Worm : Nematoda & 18 & 0.42 & 8 & 0.12 \\
\hline Worm : Naididae & 2 & 0.05 & 1 & 0.01 \\
\hline Worms: Overall & 20 & 0.46 & 9 & 0.13 \\
\hline Crustacea: Copepoda & 46 & 1.06 & 23 & 0.33 \\
\hline Crustacea:Amphipoda & 45 & 1.04 & 44 & 0.64 \\
\hline Crustacea: Ostracoda & 714 & 16.51 & 712 & 10.33 \\
\hline Crustacea: Overall & 805 & 18.61 & 779 & 11.30 \\
\hline Bacillariophyceae : Asterionella & 114 & 2.64 & 262 & 3.80 \\
\hline Bacillariophyceae: Cymbella & 149 & 3.45 & 303 & 4.39 \\
\hline Bacillariophyceae : Fragilaria & 165 & 3.82 & 472 & 6.85 \\
\hline Bacillariophyceae : Frustulia & 147 & 3.40 & 266 & 3.86 \\
\hline Bacillariophyceae: Gomphonema & 166 & 3.84 & 365 & 5.29 \\
\hline Bacillariophyceae : Navicula & 318 & 7.35 & 809 & 11.73 \\
\hline Bacillariophyceae: Pinnularia & 92 & 2.13 & 476 & 6.90 \\
\hline Bacillariophyceae : Stenopterobia & 83 & 1.92 & 342 & 4.96 \\
\hline Bacillariophyceae : Synedra & 79 & 1.83 & 343 & 4.97 \\
\hline Bacillariophyceae : Tabellaria & 80 & 1.85 & 332 & 4.82 \\
\hline Bacillariophyceae:Unidentified & 91 & 2.10 & 333 & 4.83 \\
\hline Bacillariophyceae : Overall & 1484 & 34.31 & 4303 & 62.40 \\
\hline Chlorophyceae: Spyrogyra & 266 & 6.15 & 434 & 6.29 \\
\hline Mollusca: Gastropoda & 627 & 14.50 & 131 & 1.90 \\
\hline Mollusca: Bivalvia & 372 & 8.60 & 33 & 0.48 \\
\hline Mollusca: Overall & 999 & 23.1 & 164 & 2.38 \\
\hline Plant Matter & 248 & 5.73 & 413 & 5.99 \\
\hline Detritus & 503 & 11.63 & 793 & 11.50 \\
\hline Total & 4325 & 100 & 6895 & 100 \\
\hline
\end{tabular}

Table 4: Mean and analysis of variance of stomach contents between the adult and juvenile stages of $P$. bulu sampled from Perak River, Peninsular Malaysia

\begin{tabular}{llll}
\hline Diet item categories & $\begin{array}{l}\text { Adult } \\
(\mathbf{N}=\mathbf{8 6})\end{array}$ & $\begin{array}{l}\text { Juvenile } \\
\mathbf{( N = 1 7 0 )}\end{array}$ & $\begin{array}{l}\text { ANOVA } \\
\text { (Significance) }\end{array}$ \\
\hline Worms & 1.54 & 0.69 & 0.306 \\
Crustacea & 61.92 & 59.92 & 0.849 \\
Bacillariophyceae & 51.28 & 114.15 & $0^{*}$ \\
Chlorophyceae & 20.46 & 33.38 & $0.01^{*}$ \\
Mollusca & 148.23 & 12.62 & $0.009^{*}$ \\
Plant Matter & 19.08 & 31.77 & $0.033^{*}$ \\
Detritus & 38.69 & 61.00 & $0.021^{*}$ \\
Overall food item & 404.07 & 313.53 & $0.004^{*}$ \\
\hline
\end{tabular}

population specialization and dominant prey taxon consumed by $P$. bulu inhabiting Perak River. Whereas, crustacean, detritus, plant matter and Chlorophyceae with high frequency of occurrence but lower abundance located at the bottom right of the diagram represent the general diets eaten occasionally by most individuals. Worms placed at the bottom left of the diagram were considered a rare diet item and were infrequently eaten by $P$. bulu inhabiting Perak River.

On comparing juvenile and adult stages of $P$. bulu in this population, plot diagram analysis based on Amundsen's method represent a similar pattern of feeding strategy for both stages. However, molluscs with high value of prey specific abundance and moderate value of frequency of occurrence represents specialization diet for the adult stage (Fig. 5). In contrast, molluscs and worms which were placed at the bottom left corner of the diagram were two diet groups were occasionally eaten by juvenile stage of $P$. bulu in this population (Fig. 6).

High overlaps in the diet items consumed by both adult and juvenile stages of $P$. bulu in Perak River were determined 


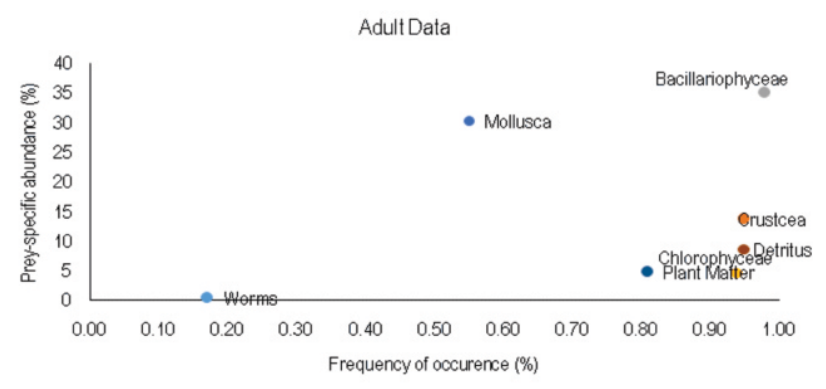

Fig. 5 : Relationship between prey-specific abundance and frequency of occurrence of the diet categories in stomach of P. bulu from Perak River, Peninsular Malaysia (adult data) based on the Amundsen's method (1996).

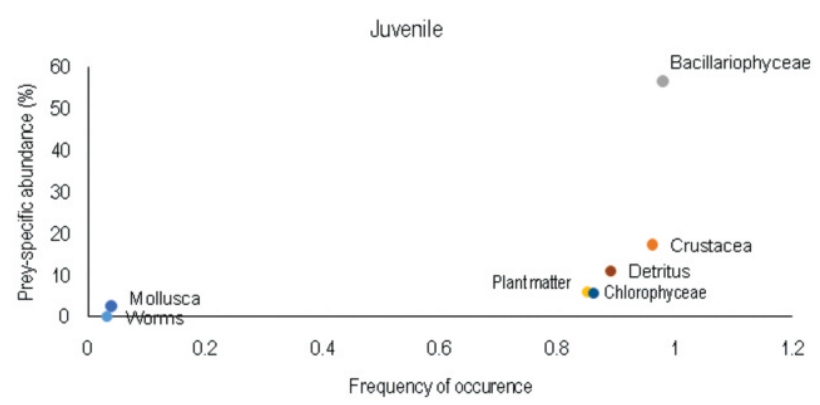

Fig. 6 : Relationship between prey-specific abundance and frequency of occurrence of diet categories in stomach of $P$. bulu from Perak River, Peninsular Malaysia (juvenile data) based on the Amundsen's method (1996).

based on Schoener's overlap index (D). The value of diet Schoener's index between these two stages was $0.715(71.5 \%)$ indicating that these two stages shared a similar diet, number of abundant preys, consequently intraspecific food competition would be a possibility.

Ontogenetic dietary changes were observed in P. bulu from Perak River population. This diet shifts are associated with morphological or behavioral changes during their ontogeny as a strategy to reduce inter and intraspecies competition in one population (Ward-Campbell and Beamish, 2005; Khaironizam, 2010; Yalcin-Ozdilek, 2016; Yazicioglu et al., 2017). Smaller mouth gape could be the reason for juvenile stage of $P$. bulu in Perak River population consuming smaller prey items compared to adult stages. Similar findings which correlate small mouth gape with small prey items have been reported by researchers in other fish species (Ward-Campbell and Beamish, 2005; Nunn, Harvey and Cowx, 2007; Khaironizam et al., 2010). Additionally, apart from morphological characters which could have been the factors influencing the dietary shift, river flow velocity and swimming capabilities might also contribute as factors which might influence the feeding strategy and diet preferences between juvenile and adult stages (Han et al., 2000; Khaironizam, 2010). Puntioplites bulu in Perak River population has a broad range of diet, however, Bacillariophyceae was consumed by this species in that population. As feeding guild of this specie has high predation on plankton, habitat degradation and river pollution might as well have a negative effect on the sustainability of this specie. Their feeding guild and strategy vary between stages. Further studies should focus attention on the correlation between maturity stage and the feeding strategy of $P$. bulu in order to provide new insight on the ecological role of each stages, thus the information gathered could facilitate in the management of this species.

\section{Acknowledgments}

The authors are thankful to the Department of Aquaculture, Universiti Putra Malaysia and the Department of Science and Biotechnology, Universiti Selangor for providing facilities and support for this study. All forms of technical assistance provided by staffs from both institutions during field sampling are greatly appreciated.

\section{References}

Al-Marzouqi, A., A. Al-Nahdi, N. Jayabalan and S. Al-Habsi: Food and feeding of the soldierbream Argyrops filamentosus (Valenciennes, 1830) from the Arabian Sea coast of Oman. Environ. Ecol., 28, 2777-2781 (2010).

Ambak, M.A., M.M. Isa, M.Z. Zakaria and M.A. Ghaffar: Fishes of Malaysia. Penerbit Universiti Malaysia Terengganu, Kuala Terengganu, Malaysia (2010).

Amundsen, P.A., H.M. Gabler and F. Staldvik: A new approach to graphical analysis of feeding strategy from stomach contents data modification of the Costello (1990) method. J. Fish. Biol., 48, 607614 (1996).

Arshad, A., R. Ara, S.M.N. Amin and A.G. Mazlan: Diet composition in larval fishes of the family Tetrapontidae (Actinopterygii: Perciformes) in the seagrass- bed of Johor Strait, Malaysia. Asian. J.Animal. Vet.Adv., 8, 325-332 (2013).

Chong, V.C., P.K.Y. Lee and C.M. Lau: Diversity, extinction risk and conservation of Malaysian fishes. J. Fish. Biol., 76, 2009-2066 (2010).

Chrisfi, P.P., P. Kaspiris and G. Katselis: Feeding habits of sand smelt (Altherina boyeri, Risso 1810) in Tichonis Lake (Western Greece). J. Appl. Ichthyol., 23, 209-214 (2007).

Costello, M.: Predator feeding strategy and prey importance: A new graphical analysis. J. Fish Biol., 36, 261-263 (1990).

Froese, R. and D. Pauly: Fishbase 2000: concept, design and data sources., https://www.worldfishcenter.org/content/fishbase-2000concepts-designs-and-data-sources (2000).

Han, C.C., K.S. Tew, I.S. Chen, L.Y. Su and L.S. Fang: Environmental biology of an endemic cyprinid, Varichorhinus alticorpus, in a subtropical mountain stream of Taiwan. Environ. Biol. Fish., 59, 153-161 (2000).

Hashim, Z.H., Y.Z. Rosli, M.S.R. Amir Shah, M.S.A. Shahrul, M.S. Mohd and M. Mashhor: Fish checklist of Perak River, Malaysia. Check List, 8, 408-413 (2012).

Hyslop, E.: Stomach contents analysis : A review of methods and their 
application. J. Fish. Biol., 17, 411-429 (1980).

Kottelat, M.: Rasbora notura, a new species of cyprinid fish from Malay Peninsula (Teleostei: Cyprinidae). Ichthyol. Explor. Fres., 16, 265270 (2005).

Kottelat, M. and E. Widjanarti: The fishes of Danau Sentarum National Park and the Kapuas lakes area, Kalimantan Barat, Indonesia. Raffles. Bull. Zool., 13, 139-173 (2005).

Kottelat, M.: The fishes of the inland waters of the Southeast Asia: A catalogue and core bibliography of the fishes known to occur in freshwaters, mangroves and estuaries. Raffles. B. Zool., 27, 1-663 (2013).

Mohan, M.V and T. Sankaran: Two new indices for stomach content analysis of fishes. J. Fish Biol., 33, 289-292 (1988).

Nunn, A.D., J.P. Harvey and I.G. Cowx: The food and feeding relationships of larval and $0+$ year juvenile fishes in lowland rivers and connected water bodies. Ontogenetic shifts and interspecific diet similarity. J. Fish. Biol., 70, 726-74 (2007).

Radhi, M.A., H. Rohasliney and H. Zarul: Fish composition and diversity in Perak, Galas and Kelantan rivers (Malaysia) after the major flood of 2014. Transylv. Rev. Syst. Ecol. Res., 19, 41-56 (2017).

Rainboth, W.J.: Fishes of the Cambodian Mekong. FAO Species Identification Field Guide for Fishery Purposes. FAO., Rome, Italy (1996).

Roshaliney, H.: Status of river fisheries in Kelantan, Peninsular Malaysia, Malaysia. Wor.Acad. Sci., Eng. Technol., 41, 801-805 (2010).

Saikia, S.K.: Food and feeding of fishes. What do we need to know? Transylv. Rev. Syst. Ecol. Res., 17, 71-84 (2015).
Schoener, T.W.: Theory of feeding strategies. Annu. Rev. Ecol. Evol. Syst., 2, 369-404 (1971).

Simon, K.D., Y. Bakar, A.G. Mazlan, C.C. Zaidi, A. Samat, A. Arshad, S.E. Temple and N.J. Brown-Peterson: Aspects of the reproductive biology of two archer fishes Toxotes chatareus, (Hamilton, 1822) and Toxotes jaculatrix (Pallas 1767). Env. Biol. Fish., 93, 491-503 (2012).

Wallace, R. K.: An assessment of diet-overlap indexes. T.Am. Fish. Soc., 110, 72-76 (1981).

Ward-Campbell, B.M.S and F.W.H. Beamish: Ontogenetic changes in morphology and diet in the snakehead, Channa limbata, a predatory fish in Western Thailand. Env. Biol. Fish., 72, 251-257 (2005).

Yalcin-Ozdilek, S.: Seasonal and ontogenetic diet shift of two sympatric cyprinid fish species from the temperate Karamenderes River, Cannakkale, Turkey. Turk. J. Zool., 41, 67-81(2017).

Yazicioglu, O., S.R. Yilmaz, M. Yazici, Yilmaz and N. Polat: Food items and feeding habits of white bream, Blicca bjoerkna (Linnaeus, 1758) inhabiting lake landik (Samsun, Turkey). Turk. J. Fish. Aqua. Sc., 17, 371-378 (2017).

Yusoff, F.M., M. Shariff and N. Gopinath: Diversity of Malaysian aquatic ecosystem and resources. Aquat. Ecosyst. Health. Manag., 9, 119-135 (2006).

Zulkafli, A.R., M.N.A. Amal, S. Shohaimi, A. Mustafa, A.H. Ghani, S. Hashim, M.I. Anuar and S. Ayub: Length-weight relationships of 15 fish species from Tembeling River, Pahang, Malaysia. J. App. Ichthyol., 32, 167-168 (2016). 